\title{
THE ANTIOXIDANT ACTIVITIES AND PHENOLIC CONTENT OF IMPROVED SOYBEAN SEEDS VARIETIES OF DIFFERENT GRAIN SIZES
}

\author{
Muchdar Soedarjo*1 | Suhartina $^{1}$ | Novita Nugrahaeni ${ }^{1}$ | Andy Wijanarko ${ }^{1}$ | Devi Anggraini \\ Putri $^{2}$ | Sri Fatmawati ${ }^{2}$
}

\begin{abstract}
${ }^{1}$ Beans and Bulbs Research Center, Indonesian Legume and Tuber Crops Research Institute, Malang, Indonesia

${ }^{2}$ Dept of Chemistry, Institut Teknologi Sepuluh Nopember, Surabaya, Indonesia

\section{Correspondence \\ * Muchdar Soedarjo, Beans and Bulbs Research Center, Indonesian Legume and Tuber Crops Research Institute, Malang, Indonesia. Email: \\ muchdar.soedarjo62@gmail.com.}

\section{Present Address}

Jl. Raya Kendalpayak km 8, PO Box 66 Malang 65101

\begin{abstract}
Tempe and tofu are the main product of soybean commonly consumed as a daily food for the people of Indonesia. So far, soybean is well known to be a source of protein. Indeed, soybean contains secondary metabolites resulting in antioxidant activities. Antioxidants would nullify the negative effect of reactive oxygen and, as a result, could improve and maintain human health. Improvement of awareness of Indonesian people that soybean is good for human health promotion and maintenance could be a trigger to enlarge the soybean production area and increase national soybean production. The present study was undertaken to evaluate the total phenolic content and antioxidant activity of some improved soybean varieties. The observation was done in three replicates, and the standard deviation was made. The results of the present study showed that total phenolic content and antioxidant activity, as measured by ABTS and DPPH, varied among the soybean seeds tested. The variability of total phenolic content and antioxidant activity was not caused by different seed sizes but by the different genetic background encoding for other phenotypes than the seed size. In general, antioxidant activity is positively correlated to total phenolic content. Demas and Tanggamus showed significantly higher antioxidant activity compared to the rest, including imported soybean. Therefore, Demas and Tanggamus could be used as better food sources for human health.
\end{abstract}

\section{KEYWORDS:}

Antioxidant Activity, Soybean, Tempe, Tofu, Total Phenolic Content 


\section{1 | INTRODUCTION}

Soybean is one of the critical food and protein sources in Indonesia. As a food source, soybean is processed as fermented products, i.e., tempe and tofu, and also are used as a daily main dish. Due to a significant decrease in national soybean production, Indonesia lacks soybean supply yearly due to unfavorable prices. Therefore, Indonesia always imports soybean every year to meet demand. For example, Indonesia imported 2.26 million tons of soybean in 2015, which is equivalent to US\$1.03 billion. Under undesirable conditions (detrimental) for growing soybean, farmers shift to other crops, such as corn and horticultural ones. An increase in soybean prices to meet the benefit of the farmers and consumers would drive the farmers' motivation to grow soybean in a larger area. In such circumstances, it is expected to increase national soybean production.

The support from the government is a possible political solution to improve the soybean price. In Japan, the government subsidizes soybean prices to farmers as much as 11.310 yen $/ 60 \mathrm{~kg}$ soybean. This policy also seems to possibly increase the capacity of domestic soybean through awareness and a better understanding of the Indonesian people. They should be aware that soybean seeds generated from conventional breeding are safe to be consumed. Soybean is believed to confer health maintenance and promotion due to high protein content and secondary compounds playing an antioxidant $1[1]$. These reasons should be disseminated to the people to acquire a special appreciation and hopefully could trigger the people to purchase soybean seeds (obtained from conventional breeding) at a higher price. It makes benefits for farmers.

The Indonesian Ministry of Agriculture, through the Agency of Agricultural Research and Development, has released more than 80 improved soybean varieties from 1918 to $2016^{6}$. In addition to high yielding, these varieties confirm resistance to some critical diseases and insects and abiotic stresses (drought and acidity). Ironically, these characters have not attracted farmers to grow soybean to a larger area. As a result, National soybean production drastically decreased, and the Indonesian Government has to import soybean to meet a domestic demand on soybean annually. As aforementioned above, if the people of Indonesia, especially those who consume soybean in their daily food, demand for soybean generated from the conventional breeding will increase, consequently. As a result, the price of such soybean will eventually be better. The present study was carried out to evaluate the degree of antioxidant activities of improved soybean varieties generated through conventional breeding.

\section{2 | MATERIAL AND METHOD}

\section{1 | Material}

Seeds of improved soybeans, as shown in Table 1 in the present work, were obtained from the Germplasm Division of Indonesian Legume and Tuber crops Research Institute, The Ministry of Agriculture, The Republic of Indonesia. The improved soybean varieties were classified with different grain sizes, as presented in Figure 1 in big, medium, and small grain sizes. Each of the enhanced soybeans was crushed into powder before further use for phenolic and antioxidant evaluation. The research was carried out at the Laboratory of Natural Products and Synthetic Chemistry, Institut Teknologi Sepuluh Nopember Surabaya.

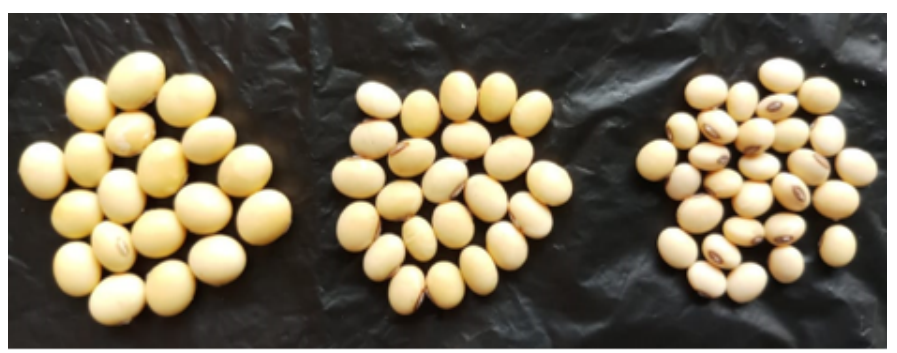

(a)

(b)

(c)

FIGURE 1 The improved soybean varieties (a) Dega 1 (big), (b) Deja 1 (medium), and (c) Gepak Kuning (small). 
TABLE 1 List of improved soybean seeds.

\begin{tabular}{|c|c|c|c|c|}
\hline \# & Varieties & Breeding History & Seed Coat Color & Seed Sizes* \\
\hline 1. & Anjasmoro & Mass selection of Manchuria & Yellow & Big \\
\hline 2. & Argomulyo & Introduction from Thailand & Yellow & Big \\
\hline 3. & Burangrang & Selected from farmers' field in Jember & Yellow & Big \\
\hline 4. & Grobogan & Selected from Gerobogan & Yellow & $\mathrm{Big}$ \\
\hline 5. & Dega 1 & Gerobogan x Malabar & Yellow & Big \\
\hline 6. & Deja 2 & Sibayak x Grobogan & Yellow & Big \\
\hline 7. & Dena 1 & Argomulyo x IAC 100 & Yellow & $\mathrm{Big}$ \\
\hline 8. & Detap 1 & G $511 \mathrm{H}$ x Anjasmoro & Yellow & Big \\
\hline 9. & Devon 1 & Kawi x IAC 100 & Yellow & Big \\
\hline 10. & Panderman & Introduksi dari Taiwan & Yellow & $\mathrm{Big}$ \\
\hline 11. & Demas & Mansuria x SJ & Yellow & Medium \\
\hline 12. & Dering 1 & Davros x MLG 2984 & Yellow & Medium \\
\hline 13. & Deja 1 & Tanggamus x Anjasmoro & Yellow & Medium \\
\hline 14. & Dena 2 & IAC $100 \times$ Ijen & Yellow & Medium \\
\hline 15. & Tanggamus & Kelinci x No. 3911 & Yellow & Medium \\
\hline 16. & Wilis & Orba x No. 1682 & Yellow & Medium \\
\hline 17. & Gamasugen & Mutant of soybean var. Tidar & Yellow & Medium \\
\hline 18. & Kaba & Crossing among 16 parental soybean & Yellow & Medium \\
\hline 19. & Gepak Hijau & Selected from a local variety & Green yellowish & Small \\
\hline 20. & Gepak Kuning & Selected from a local variety & Green yellowish & Small \\
\hline 21. & Imported (USA) & purchased the tempe cooperative in Malang & Yellow & $\mathrm{Big}$ \\
\hline
\end{tabular}

\section{2 | Determination of Total Phenolic Content}

Each soybean powder was dissolved into methanol at a final concentration of $1 \mathrm{mg} / \mathrm{mL}$ and was considered as a sample. Sixtysix microliter of each sample and $500 \mu \mathrm{L}$ reagent of $10 \%$ Folin was mixed thoroughly and was incubated in the darkroom for 5 minutes. Afterward, $500 \mu \mathrm{L}$ of $6 \% \mathrm{Na}_{2} \mathrm{CO}_{3}$ was added into the mixture and was stirred thoroughly and was further incubated in the darkroom for 90 minutes. Finally, each sample was determined by a spectrophotometer at $\lambda$ equal to $750 \mathrm{~nm}$. Each sample was measured at three replicates, and the reading was presented as mg gallic acid equivalent eq (GAE)/g sample ${ }^{77}$.

\section{3 | Determination of Antioxidant Activity by ABTS}

Free radical solution of ABTS (2,2'-and-bis(3-ethylbenzthiazoline-6-sulfonic acid) was prepared by mixing $5 \mathrm{~mL}$ of $7 \mathrm{mM}$ ABTS and $88 \mu \mathrm{L}$ of $140 \mathrm{mM} \mathrm{K} 2 \mathrm{~S} 2 \mathrm{O} 8$. This free radical solution was incubated in the darkroom at room temperature for 16 hours. Afterward, $300 \mathrm{ml}$ ethanol was added into the free revolutionary solution to reach absorbance of $0.7 \pm 0.02$ units at $\lambda$ $734 \mathrm{~nm}$. Furthermore, the sample solution (As) was measured by a UV-Vis spectrophotometer at $\lambda$ equal to $734 \mathrm{~nm}$. The sample solution is ten $\mu \mathrm{L}$ of the sample ( $10 \mathrm{mg} / \mathrm{mL}$ sample in DMSO) and $1 \mathrm{~mL}$ of ABTS solution incubated for four minutes. Each sample was measured at triplicates. Trolox was used as a positive control. DMSO was used as a negative control or blank (Ab). The reading was done in three replicates for each sample, and the standard deviation was calculated based on the three replicates. The inhibitory activity was measured by formula (1).

$$
\text { Antioxidant activity }(\%)=\frac{A b-A s}{A b} \times 100
$$

\section{4 | Determination of Antioxidant Activity by DPPH}

Antioxidant activity was measured by employing the method of Brand Williams et al. 9 after a slight modification by Dudonne et al. [10]. The methanolic extracts of soybean seeds were dissolved in methanol (analytical grade) to maximum concentration. A DPPH solution (2,2-diphenyl-2-picrylhydrazyl hydrate) was dissolved in methanol to a final concentration of 6x10-5 M. Extract of each sample $(33.3 \mu \mathrm{L})$ was poured into a test tube containing $1 \mathrm{ml} \mathrm{DPPH}$, mixed thoroughly and the mixture was named as 'As.' The negative control consists of $33.3 \mu \mathrm{L}$ methanol thoroughly mixed with $1 \mathrm{ml} \mathrm{DPPH}$ solution. This mixture solution was designated as Ab. Gallic acid was used as a positive control. The mixture of all samples (As) and the mixture of the negative control $(\mathrm{Ab})$ were incubated at $37^{\circ} \mathrm{C}$ for 20 minutes. Right after the incubation, the absorbance of the combination of each sample 


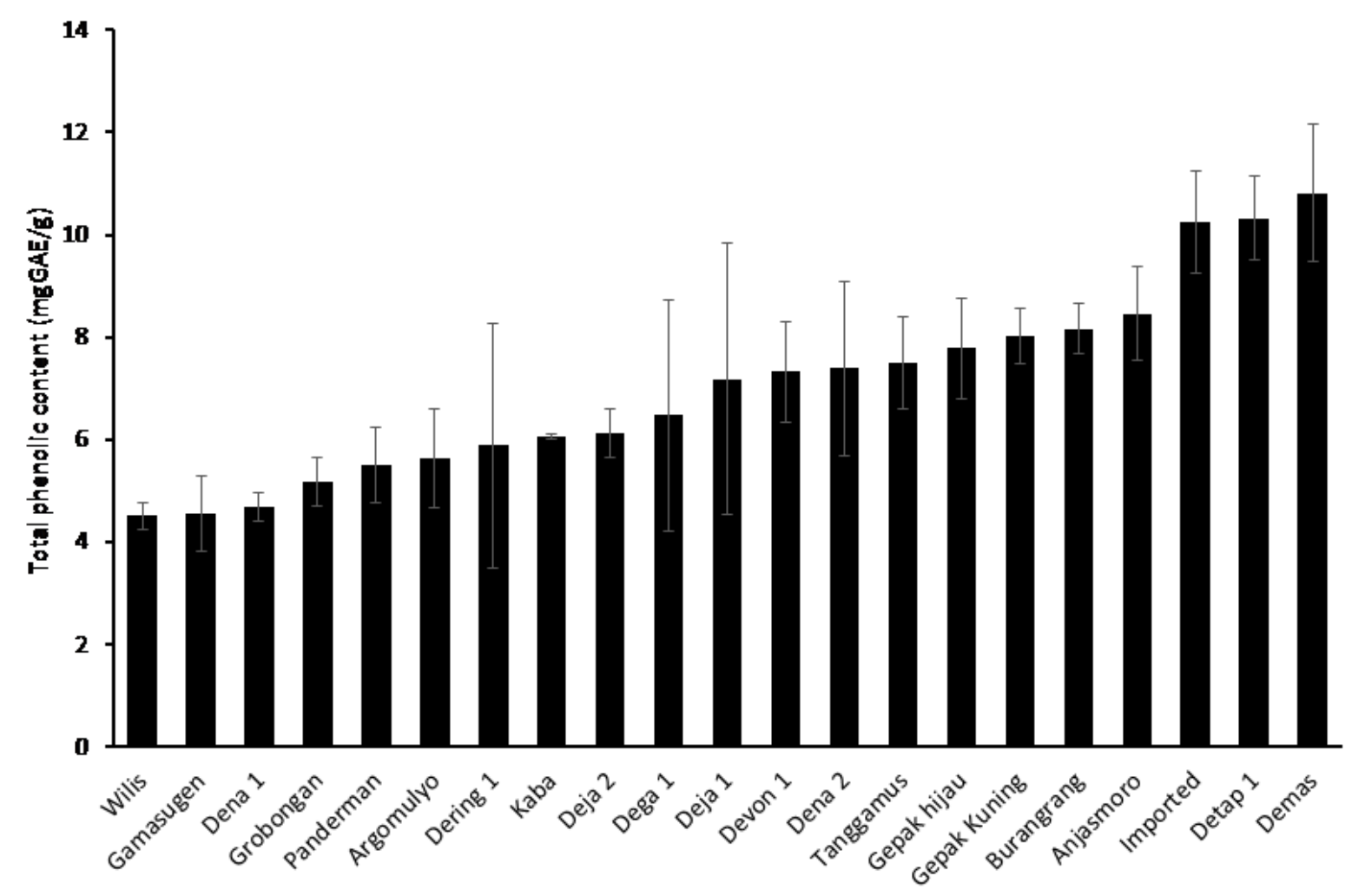

FIGURE 2 The total phenolic content of improved soybean seeds varieties.

(As) and the mixture of (Ab) was read with a spectrophotometer at $515 \mathrm{~nm}$. The reading was done in three replicates for each example, and the standard deviation was calculated based on it. The degree of antioxidant activity was calculated as formula (1).

\section{3 | RESULTS AND DISCUSSION}

\section{1 | Total Phenolic Content}

As depicted in Figure 2 , the total phenolic content varied significantly among the improved soybean varieties tested. The soybean varieties used in the present study have different genetic background (see Table 1). Thus, variability in the ancestral knowledge leads to various figures in the total phenolic compound. Two improved conventional breeding, i.e., Demas and Detap 1 , showed the highest total phenolic content, comparable to the value of 10.81 and $10.32 \mathrm{mgGAE} / \mathrm{g}$, respectively, as an imported soybean. In contrast, Dena 1, Wilis, and Gamasugen have the lowest phenolic compound, and these varieties are classified as medium seed size soybean. Detap and imported soybean have similar seed size (classified as big seed), while, Demas is classified as a medium seed size variety. The results of the present the study revealed an inconsistent relationship between the seed size and total phenolic content, meaning that big or smaller seed is not always followed with higher or lower total phenolic content. Therefore, seed size is not a determinant for the variability of total phenolic compounds in soybean seed. In addition, the seed coat all soybean tested showed yellow extract and resulted in various total phenolic compounds (Figure 2 . This present study also suggests that each soybean seed has a difference in total phenolic. The result of the present study follows the results reported by previous researchers [11 [13. They also reported that in addition to the genetic background, growing location also caused the variability of total phenolic compounds. The soybean seeds used in the present study were provided by the Division of germplasm and could obtain from the harvest of different sites and seasons. 


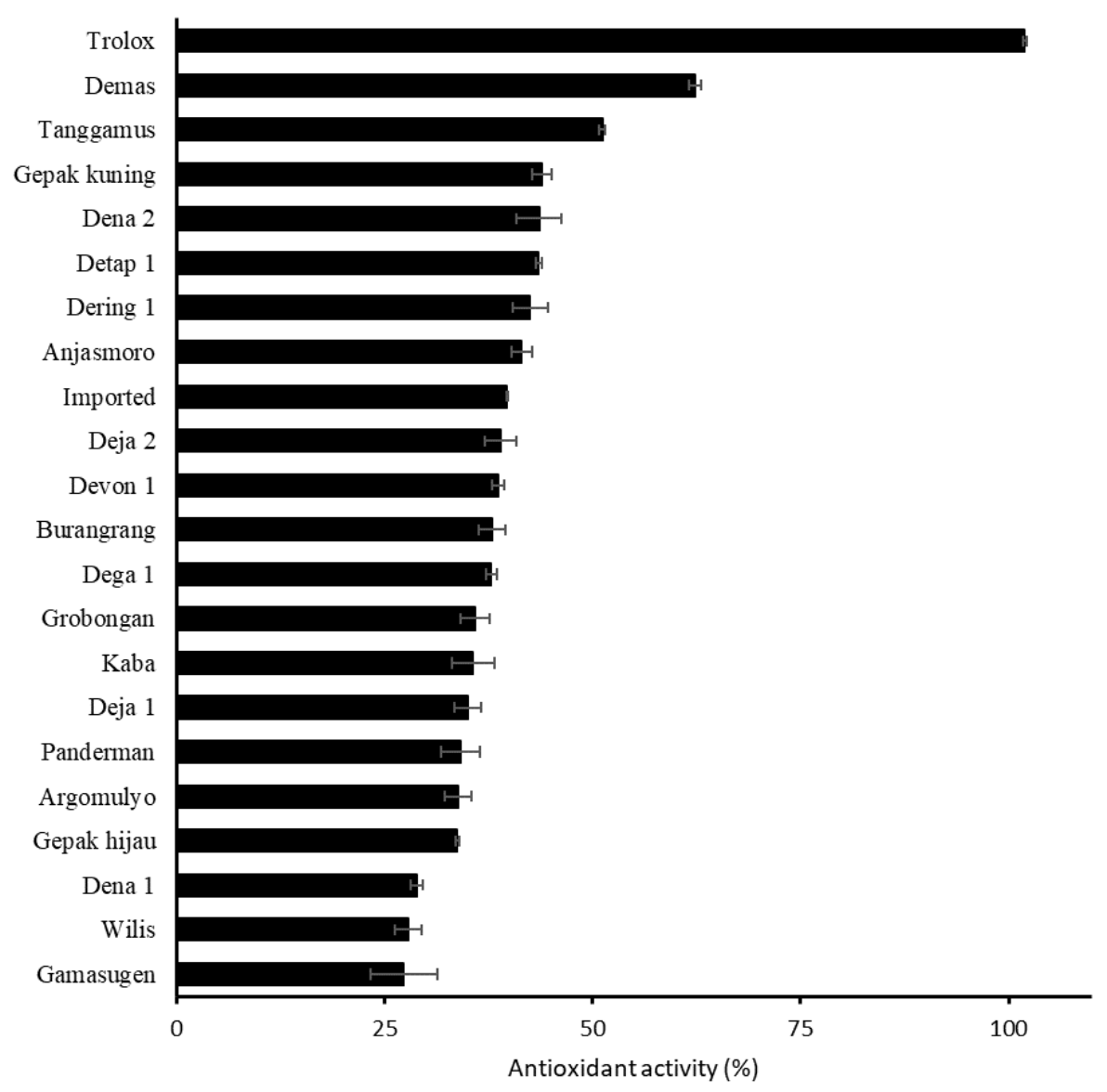

FIGURE 3 Antioxidant activity of improved soybean seeds varieties against ABTS at a concentration of $99 \mu \mathrm{g} / \mathrm{mL}$.

\section{2 | Antioxidant Activity by ABTS Method}

Figure 3 presented a variability of antioxidant activity among the soybean seeds tested as measured by the ABTS method. The variability of antioxidant activity was observed within the big size, within the medium size and small size soybean seeds, suggesting that the genes encoding for the phenotype of seed sizes are not all good character in determining variability of antioxidant activity. Within the medium size seed, Demas showed the highest antioxidant activity with antioxidant activity of $62.26 \%$, but its antioxidant activity is not significantly different from Tanggamus soybean with inhibitory activity of $51.15 \%$. Dena 2 and Demas, classified as a medium-size seed, possessed comparably high antioxidant activity compared to Detap 1, Anjasmoro, and imported soybean, belonging to the big size seed. Interestingly, Gepak Hijau (the small size seed group) revealed the minor antioxidant activity and significantly lower from the rest of the soybean seed tested. However, the antioxidant activity of Gepak Kuning (the small size seed group) similar to that of Argomulyo, Dega 1 and Devon 1 (the big size seed group), Dering 1 (the medium size seed group). Thus, the relationship between seed size and antioxidant activity leads to an assumption that the genes encoding for other phenotypes contribute to the variability of antioxidant activity measured ABTS as well as DPPH. The previous findings revealed that different genetic backgrounds within plant species caused a variability of antioxidants measured with ABTS 14 15.

\section{3 | Antioxidant Activity by DPPH Method}

Antioxidant activities of soybean seeds measured with the DPPH method varied among soybean varieties tested (Figure 4 . Interestingly, some improved varieties, such as Detap 1, Anjasmoro, and Dena 2, showed significantly higher antioxidant activity with inhibitory activity of $29.66 \%, 29.13 \%$, and $28.35 \%$, respectively compared to imported soybean with inhibitory activity 


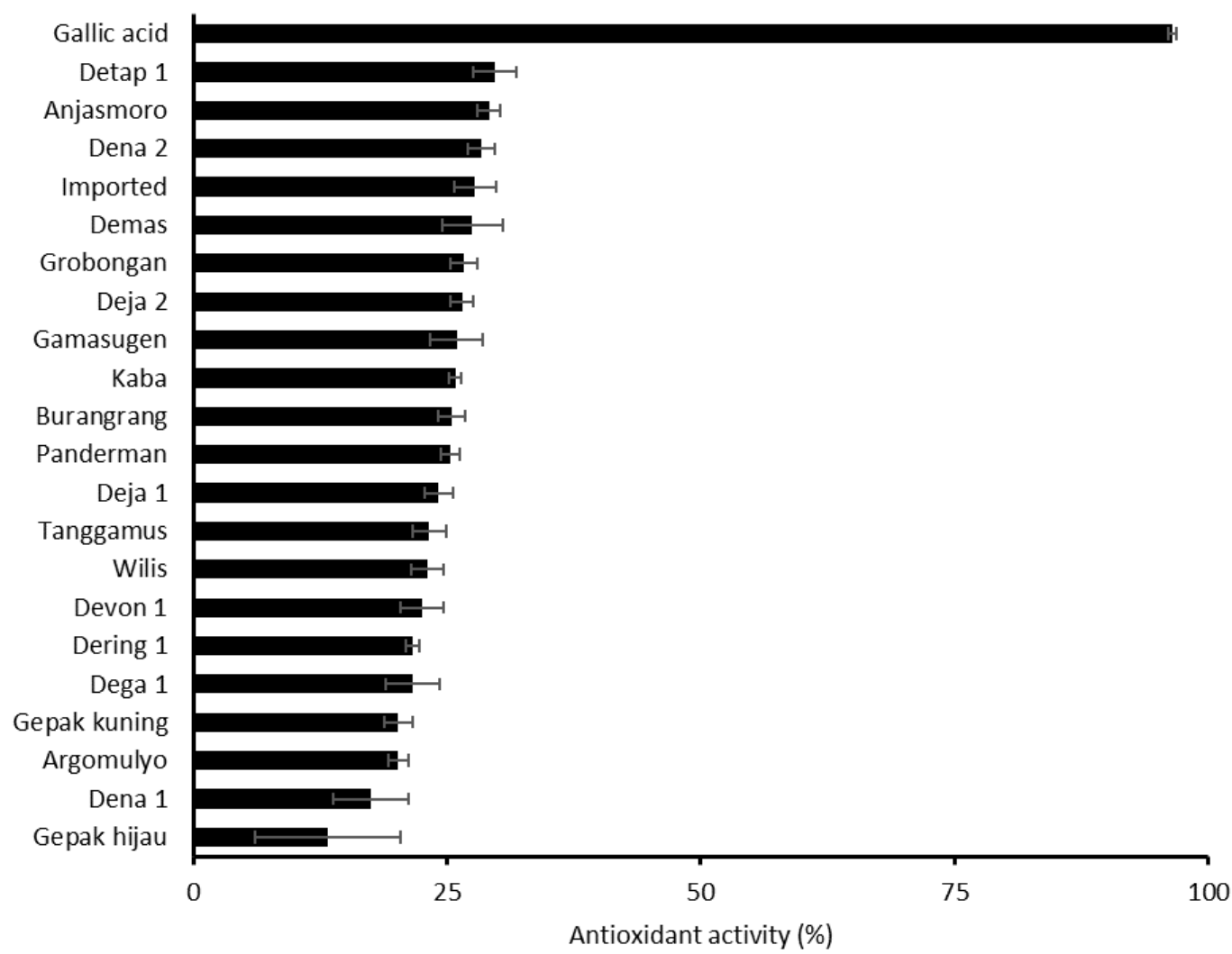

FIGURE 4 Antioxidant activity of improved soybean seeds varieties against DPPH at a concentration of $619 \mu \mathrm{g} / \mathrm{mL}$.

TABLE 2 Correlation analysis between total phenolic content and antioxidant activity.

\begin{tabular}{lll}
\hline & Antioxidant by ABTS & Antioxidant by DPPH \\
\hline Total phenol & $\mathrm{r}=0,348254(\mathrm{~ns})$ & $\mathrm{r}=0,730674\left({ }^{*}\right)$ \\
Note & Weakly correlated & Highly correlated \\
\hline
\end{tabular}

of $27.75 \%$. The rest of our improved soybean seeds revealed a comparable antioxidant activity to imported soybean seed. The present research result indicates the variability of antioxidant activity among the soybean seeds of different genetic backgrounds. Variability of antioxidant activity measured with the DPPH method due to the genetic variability of soybean was also reported elsewhere [13]16]. Imported soybean seed is well known to be genetically modified varieties. The results of the present study suggest that our improved soybean varieties generated through conventional breeding, Demas, and Tanggamus, were found to be a better source of food due to the relatively higher antioxidant activity.

\section{4 | Correlation Between Phenolic Content and Antioxidant Activity}

Correlation value ( $\mathrm{r}$ ) between total phenolic compound and antioxidant activity measured by the ABTS method was found to be moderately correlated $(\mathrm{r}=0,348254)$ and is not significant at $5 \%$ (Table 2). On the other hand, the total phenolic compound of soybean seed was highly correlated with antioxidant activity measured with the DPPH method. The correlation was found to be significant at $1 \%$. This correlation analysis suggests that high phenol content of soybean seed is followed with high antioxidant activity when measured with the DPPH method. The present study is supporting the research results reported by several researchers who found a positive correlation between total phenol and antioxidant activities in soybean and other plant species [12] 14 [6] 22]. Therefore, it could be suggested that total phenol is a good initial indicator of antioxidant activities. 


\section{4 | CONCLUSION}

Total phenolic content and antioxidant activity, as measured by ABTS and DPPH, varied among the soybean seeds tested. The variability of total phenolic content and antioxidant activity was not caused by different seed size but by the different genetic background encoding for phenotype other than the seed size. In general, antioxidant activity is positively correlated to total phenolic content. Demas and Tanggamus showed significantly higher antioxidant activity compared to the rest, including imported soybean. Therefore, Demas and Tanggamus could be suggested as better food sources for human health.

\section{5 | ACKNOWLEDGMENT}

We thank the Indonesian Ministry of Agriculture for financial support to the present research work through State Budget (APBN) year 2018 .

\section{References}

1. Wu N, Fu K, Fu YJ, Zu YG, Chang FR, Chen YH, et al. Antioxidant Activities of Extracts and Main Components of Pigeonpea [Cajanus cajan (L.) Millsp.] Leaves. Molecules 2009;14(3):1032-1043.

2. Doss A, Pugalenthi M, Vadivel V. Antioxidant Activity of Raw and Differentially Process Under-Utilized TropicaLegume Canavalia Ensiformis L. DC Seeds, South India. IIOABJ 2011;2(8):27-32.

3. Mujic IO, Sertovic E, Jokic S, Saric Z, Alibabic V, Vidovic S, et al. Isoflavone Content and Antioxidant Properties of Soybean Seeds. Croatian Journal of Food Science and Technology 2011;3(1):16-20.

4. Sefatie RS, Fatoumata T, Eric K, Shi YH, Guo-Wei L. In Vitro Antioxidant Activities of Protein Hydrolysate from Germinated Black Soybean (Glycine max L.). Advance Journal of Food Science and Technology 2013;5(4):453-459.

5. Pertiwi SF, Aminah S, Nurhidajah N. Aktivitas Antioksidan, Karakteristik Kimia, dan Sifat OrganoHitam (Glycine soja) Berdasarkan Variasi Waktu Perkecambahan. Jurnal Pangan dan Gizi 2013;4(2):1-8.

6. Pusat Penelitian dan Pengembangan Tanaman Pangan Badan Penelitian dan Pengembangan Pertanian. Deskripsi Varietas Unggul Kacang-Kacangan dan Umbi-Umbian. Malang, Indonesia: Balai Penelitian Tanaman Aneka Kacang dan Umbi; 2016.

7. Al-Qassabi JSA, Weli AM, Hossain MA. Comparison of Total Phenols Content and Antioxidant Potential of Peel Extracts of Local and Imported Lemons Samples. Sustainable Chemistry and Pharmacy 2018;8:71-75.

8. Putri DA, Ulfi A, Purnomo AS, Fatmawati S. Antioxidant and Antibacterial Activities of Ananas Comosus Peel Extracts. Malaysian Journal of Fundamental and Applied Sciences 2018;14(2):307-311.

9. Brand-Williams W, Cuvelier ME, Berset C. Use of a Free Radical Method to Evaluate Antioxidant Activity. LWT - Food Science and Technology 1995;28(1):25-30.

10. Dudonne S, Vitrac X, Coutiere P, Woillez M, Merillon JM. Comparative Study of Antioxidant Properties and Total Phenolic Content of 30 Plant Extracts of Industrial InterestUsing DPPH, ABTS, FRAP, SOD, and ORAC Assays. Journal of Agricultural and Food Chemistry 2009;57(5):1768-1774.

11. Sakthivelu G, Akitha Devi MK, Giridhar P, Rajasekaran T, Ravishankar GA, Nikolova MT, et al. Isoflavone Composition, Phenol Content, and AntioxidantActivity of Soybean Seeds from India and Bulgaria. Journal of Agricultural and Food Chemistry 2008;56(6):2090-2095.

12. Lee LS, Choi EJ, Kim CH, Kim YB, Kum JS, Park JD. Quality Characteristics and Antioxidant Properties of Black and Yellow Soybeans. Korean Journal of Food Science and Technology 2014;46(6):757-761. 
13. Prvulovic D, Malencic D, Miladinovic J. Antioxidant Activity and Phenolic Content of Soybean Seeds Extracts. Agroknowledge Journal 2017;17(2):132.

14. Mikulajova A, Takacsova M, Rapta P, Brindzova L, Zalibera M, Nemeth K. Total Phenolic Contents and Antioxidant Capacities ofCereal and Pseudocereal Genotypes. Journal of Food and Nutrition Research 2007;46(4):150-157.

15. Singh J, Kanaujia R, Kumar J, Singh F, Srivastava A, Singh N. Genetic Variability for Antioxidant Activity and Total Phenolic Content in four Major Pulse Crops. Novel Techniques in Nutrition \& Food Science 2018;1(2):43-48.

16. Malencic D, Popovic M, Miladinovic J. Phenolic Content and Antioxidant Properties of Soybean (Glycine max (L.) Merr.) Seeds. Molecules 2007;12(3):576-581.

17. Stankovic MS. Total Phenolic Content, Flavonoid Concentration and Antioxidant Activity of Marrubium Peregrinum L. Extracts. Kragujevac Journal of Science 2011;33:63-72.

18. Rebaya A, Belghith SI, Baghdikian B, Leddet VM, Mabrouki F, Olivier E, et al. Total Penolic, Total Flavonoid, Tannin Content, and Antioxidant Capacity of Halimium Halimifolium (Cistaceae). Journal of Applied Pharmaceutical Science 2015;5(1):52-57.

19. Amzad Hossain M, Shah MD. A study on the Total Phenols Content and Antioxidant Activity of Essential Oil and Different Solvent Extracts of Endemic Plant Merremia Borneensis. Arabian Journal of Chemistry 2015;8(1):66-71.

20. Fidrianny I, Elviana D, Ruslan K. In Vitro Antioxidant Activities in Various Beans Extracts of Five Legumes from West of Java-Indonesia Using DPPH and ABTS Methods. International Journal of Pharmacognosy and Phytochemical Research 2016;8(3):470-476.

21. Khalid S, Ahmad A, Kaleem M. Antioxidant Activity and Phenolic Contents of Ajwa Date and Their Effect on Lipo-Protein Profile. Functional Foods in Health and Disease 2017;7(6):410.

22. Parikh B, Patel VH. Quantification of Phenolic Compounds and Antioxidant Capacity of an Underutilized Indian fruit: Rayan [ Manilkara hexandra (Roxb.) Dubard]. Food Science and Human Wellness 2017;6(1):10-19.

How to cite this article: Soedarjo M., Suhartina S., Nugrahaeni N., Wijanarko A., Putri D.A., Fatmawati S., (2020), The Antioxidant Activities and Phenolic Content of Improved Soybean Seeds Varieties of Different Grain Sizes, IPTEK The Journal of Technology and Science, 31(1):83-90. 